UDC 577.325

\author{
A. I. Kornelyuk, A. G. Terentiev, S, Fisher, T. Porter
}

\title{
Synthesis and characterization of fluorogenic peptide substrate of HIV-1 protease based on fluorescence resonance energy transfer
}

Synthesis of furorogenic peptide substrate of HIV-1 protecase Dns-SQNYPIVWh, which corresponds to the pI7/p24 cleavase site for HIV-I protecase have been performed. This fluorogenic substrate was based on the fluonetcence resonance energy transfer between donor - Trp residue, and acceptor - dansyl group in the intact peptide. Hydrolysis of substrate by recombinant $M I V-I$ protease resulted in the time-dependent increase of Trp fluorescence and decrease of dansyl fluorescence measured at 350 and $500 \mathrm{~nm}$, respectivety, due to the break of resonance energy transfer between donor and acceptor fluorophors. Hydrolysis of fluorogenic peptide substrote was studied also by reversed phase HPLC and two peptide fragments after cleavage of substrate have been detected. Kinetic constants of hydrolysis for this fluorogenic peptide substrate by $M I V-I$ protease were calculated from Lineweaver - Burk plots: $K_{M}-29 \mu \mathrm{M}, k_{\text {cat }}=5.4 s^{-1}$ and $k_{\text {ear }} / K_{M}-$ $180000 \mathrm{M}^{-1} \mathrm{~s}^{-1}$.

Introduction. Human immunodeficiency virus protease (HIV-1 protease) performs the proteolytic processing of viral gag and gag-pol polyproteins precursors during the replication cycie of retrovirus $[1,2]$. It has been shown using site directed mutagenesis and aiso by use of specific inbibitors of HIV-1 protease that disruption of this function produces morphologically immature and noninfectious viral particles [3]. Thus, HIV-1 protease represents an important therapeutic target in the development of treatment for AIDS [4]. The number of specific inhibitors of HIV-1 protease have been synthesized and studied and results are summarized in reviews [5, 6]. The antivirus synergy between HIV-1 protease inhibitors and nucieoside analogue inhibitors of HIV reverse transcriptase (AZT, ddC) has been also revealed [7]. •

Evaluation of efficiency of novel HIV-1 protease inhibitors requires the rapid and sensitive method of measurement of protease activity. Recently chromophoric peptide substrate for the spectrophotometric assay of HIV-1 protease have been reported $[8]$, which exhibits an absorbance increase upon its hydrolysis by protease. Fluorogenic peptide substrates of HIV-1 protease [9-11] are most efficient and sensitive in the monitoring of specific hydrolysis reaction.

In this work we report the synthesis and characterization of fluorogenic peptide substrate of HIV-1 protease based on fluorescence resonance energy transfer (FRET). Resonance energy transfer between donor and acceptor chromophores is widely used as a tool for the measurement of intramolecular distances in biopolymers [12] and also to monitor the enzyme activity [9-11, 13]. Our substrate was based on the FRET between two fiuorescent probes, tryptophan and dansyl group, introduced into the oligopeptide substrate, which corresponds to the $p 17 / p 24$ cleavage site for HIV-1 protease.

Materials and Methods. Purification of $H I V-I$ protease. The expression system in Escherichia coli strain AR58 was as previously described by Meek et al. [14]. Cells $(300 \mathrm{~g})$ were thawed in $1500 \mathrm{ml}$ of $50 \mathrm{mM}$ Tris buffer containing 
$5 \mathrm{mM}$ EDTA, $10 \mathrm{mM}$ DTT and $1 \mathrm{mM}$ PMSF, pH 8.0 and lysed with one pass through a Rainie cell disrupter at $6000 \mathrm{psi}$. Following centrifugation of the lysate at $30.000 \times g$ for $60 \mathrm{~min}$, the supernatant was drawn off and solid ammonium sulfate was added slowly to $35 \%$ final concentration. After stirring for $60 \mathrm{~min}$ at $4^{\circ} \mathrm{C}$, the mixture was allowed to settle for $30 \mathrm{~min}$ prior to centrifugation at $30.000 \times g$ for $60 \mathrm{~min}$. The pellet was resuspended in a minimal volume of Superose 12 chromatography buffer $(50 \mathrm{mM}$ Tris buffer containing $5 \mathrm{mM}$ EDTA, $10 \mathrm{mM}$ DTT, $200 \mathrm{mM} \mathrm{NaCl}$ and $10 \%$ glycerol, pH 8.0) and dialyzed overnight at $4^{\circ} \mathrm{C}$ against the same buffer. The dialysate was then clarified by centrifugation at $30.000 \times g$ for 30 min and applied to a Superose 12 column (5 liters). Fractions were collected and assayed for HIV-1 protease by reversed phase HPLC (RP-HPLC) and peak activity fractions were pooled, made $40 \%$ v/v with glycerol and stored at $-70^{\circ} \mathrm{C}$. The protein was judged to be greater than $95 \%$ pure by SDS-PAGE and RP-HPLC analysis. Protease activity assay was conducted according to [14] with substrate Ac-RASQNY $\cdot$ PVV-NH $\mathrm{NH}_{2}$.

Synthesis of fluorogenic peptide substrate Protected amino acids Boc-Leu, Boc-lle, Boc-Val, Boc-Pro, Boc-Asn, Boc-Gin, N(a)-Boc-O-benzyl-L-Ser, $\mathrm{N}(a)$-Boc-O-benzyl-L-Tyr and $\mathrm{N}(\alpha)$-Boc-(jndolylformyl)-L-Trp were synthesized as described [15].

Synthesis of fluorogenic peptide substrate of DnsSerGlnAsnTyrProlleValTrplen-OH was performed by peptide synthesizer using Merrifield resin (chloromethylated copolymer of styrol and divinylbenzole, particle size of $200-400$ mesh and active chlorine content of 0.7 mmole per $1 \mathrm{~g}$ of resin) obtained from Fluka (Switzerland). For synthesis convenience $N(a)$-Boc-Leu has been attached to the polymer as C-terminal amino acid by means of potassium salt in the presence of 18-crown-6-ether as catalyst [16].

$\mathrm{H}_{2} \mathrm{~N}$-SerGlnAsnTyrProlleVaITrpLeu-resin was dansylated by Dns-Cl. Dansylated peptide was isolated by pass of bromide hydrogen for $90 \mathrm{~min}$ through the resin suspension in trifluoroacetic acid (TFA), containing thioanizole. Formylation protection of $\mathrm{Trp}_{\mathrm{p}}$ was removed by $0.1 \mathrm{M}$. triethylamine in $\mathrm{H}_{2} \mathrm{O}$ for $10 \mathrm{~min}$ at $0^{\circ} \mathrm{C}$. The crude peptide ( $52 \mathrm{mg}$ ) was then purified to homogeneity by RP-HPLC.

$H P L C$. Substrate purification, as well as the analysis of peptide fragments after cleavage of substrate by HIV-1 protease were performed on a Gold System (Beckman), using either Ultrasphere $\mathrm{C}-18$ column $(10 \times 250 \mathrm{~mm})$ or Ultrasphere C-18 IP column $(4.6 \times 45 \mathrm{~mm})$. Linear ehtion gradient of 0 to $80 \%$ acetonitrile in $0.1 \%$ TFA was used in HPLC experiments.

Fluorescence measurements; All measurements were performed on the Hitachi Model 850 fluorescence spectrophotometer (Japan), with a thermostated cell compartment at $20^{\circ} \mathrm{C}$. Fluorescence measurements were performed in $0.5 \times 0.5 \mathrm{~cm}^{2}$ quartz microcuvette.

Fluorogenic peptide substrate Das-SQNYPIVWL-OH was dissolved in $50 \%$ isopropanol. Then peptide solution was diluted by addition of reaction buffer, containing $0.05 \mathrm{M}$ sodium acetate, pH 5.5, $0.01 \mathrm{M}$ dithiotreitol and $10 \%$ glycerol.

Kinetic analysis. Kinetic constants were determined from the fluorescence assay data of hydrolysis of fluorogenic substrate by HIV-1 protease. Initial rate of hydrolysis was calculated according to [17] as: $v=F_{l}[S] /\left(F-F_{0}\right) t$, where $v$ - initial rate of hydrolysis $(\mu \mathrm{mole} / \mathrm{min}),[S]-$ concentration of substrate ( $u$ mole), $F_{t}$ - fhrorescence intensity of substrate at the time $t$ ( $t$ - time of hydrolysis, $\min ), F$ - fluorescence intensity after complete hydrolysis and $F_{0}$ - initial fluorescence intensity. The kinetic parameters were obtained from the Lineweaver - Burk plots after linearization procedure performed using "Enzfitter" program. 
Results. Design of structure of fluorogenic substrate. The amino acid sequence which corresponds to the $p / 7 / p 24$ cleavage site for HIV-1 protease was selected. This sequence was selected because it had been shown to be a better substrate for cleavage by HIV-1 protease than synthetic peptides based on other cleavage sites [18].

Trp residue was introduced into $\mathrm{C}$-terminus of oligopeptide as a donor fluorophor $\left(\lambda_{\max }\right.$ at $\left.355 \mathrm{~nm}\right)$ and dansyl group at $N$-terminus served as an acceptor fluorophor $a_{\max }$ at $\left.520 \mathrm{~nm}\right)$. Substrate design was based on the FRET between donor and acceptor groups in the intact peptide. Proteolytical cleavage of substrate by HIV-1 protease at the Tyr-Pro site should release two fluorophor-peptide fragments and break resonance energy transfer between Trp and Dns with concomitant changes of fluorescence intensities both of donor and acceptor fluorophors.

Fluorescence properties of substrate. Fluorescence of fluorogenic substrate was excited at $290 \mathrm{~nm}$ and corrected emission spectra were recorded. Two emission bands at 355 and $520 \mathrm{~nm}$ (Trp and Dns emissions) were observed in the spectra. The ratio of fluorescence intensity of Dns to Trp fluorescence was about $1.8 \rightarrow 2.0$ in the intact substrate.

Hydrolysis of substrate by HIV-I protease. Addition of HIV-1 protease $\left(1.9 \cdot 10^{-7} \mathrm{M}\right)$ to substrate solution in the reaction buffer resulted in the changes of intensities of both fluorescence emission bands. Time-dependent increase of relative emission intensity of Trp fluorescence and decrease of dansyl fluorescence measured at 350 and $500 \mathrm{~nm}$, respectively, are shown in Figure. These fluorescence changes were apparently due to the break of FRET between donor and acceptor fluorophors.

Fuoreacence intensities changes (excitation wavelength $290 \mathrm{~nm}$ ) of Dms-SQNYPIVWL-OH (concentration of $\left.2.5 \cdot 10^{-5} \mathrm{M}\right)$ in the course of its hydrolydis by HIV-1 protease. Protease concentration was $1.9 \cdot 10^{-7} \mathrm{M} . I-$ relattve mtensity change of tryptophan fluorescence meagured at $350 \mathrm{~nm} ; 2$ - relative intensity change of dansyl fluoreacence meatured at $500 \mathrm{~nm}$

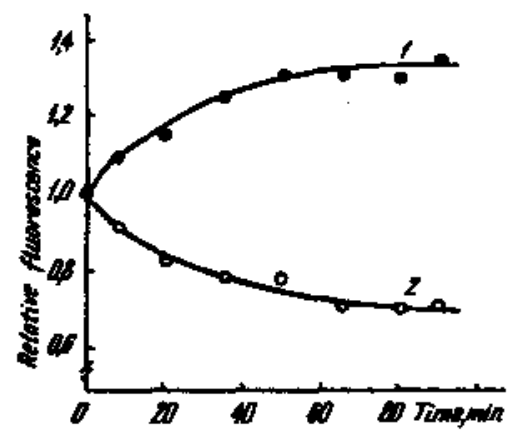

Hydrolysis of fliorogenic peptide substrate was studied also by RP-HPLC. Action of HIV-1 protease on Dns-SQNYPIVWL resulted in the appearance of two new peaks with retention times of 12.5 and $15.2 \mathrm{~min}$. These species were characterized by fluorescence spectroscopy and identified as substrate fragments Dns-SQNY and PIVWL. These results suggest that fluorogenic substrate had been cleaved by HIV-1 protease at Tyr-Pro site.

Kinetic parameters of hydrolysis. Kinetic studies of the hydrolysis reaction were performed at nine different concentrations of fluorogenic substrate. The kinetic constants of HIV-1 protease-catalyzed cleavage were calculated from Lineweaver - Burk plots. For this fluorogenic peptide substrate the values $K_{\mathrm{M}}=29 \mu \mathrm{M}$ and $k_{\mathrm{at} 1}=5.4 \mathrm{~s}^{-1}$ were obtained. These kinetic constants are close to the values obtained by Matayoshi et al. [9] for the hydrolysis of fluorogenic substrate based on the same $p 17 / p 24$ cleavage site $\left(K_{M}=103 \mu \mathrm{M}\right.$ and $k_{\text {tat }}=4.9 \mathrm{~s}^{-1}$, respectively). 
Discussion. Different methods have been used for the measurement of proteolytic activity of HIV-proteases, including HPLC analysis of cleavage fragments [14], protein immunoblot analysis, spectrophotometric assay using chromophoric peptide substrate [8]. Most of these methods are time-consuming and unacceptable for screening of large number of HIV-protease inhibitors.

Fluorogenic peptide substrates of HIV-1 protease are based on fluorescence assay of its proteolytic activity. This method is very sensitive and provides an accurate determination of kinetic parameters of hydrolysis reaction.

Fluorogenic peptide substrate of HIV-1 protease Dns-SQNYPIVWL described in this work was based an the FRET between Trp as a donor and Dns as an acceptor molecules. This donor-acceptor pair is very suitable for energy transfer measurements. It is known that FRET measurements are most sensitive to distance variation when donor-acceptor separation is close to their Förster distance [12]. The value of Förster distance using Trp as a donor and Dns as an acceptor of resonance energy transfer $R_{0}=21 \AA[12]$, which corresponds well to the length of peptide separating two fluorescent probes in fluorogenic substrate. Our fluorogenic substrate is similar to substrate described by Geoghegan et al. [11] but it has much better ratio $k_{c a t} / K_{M}=180000 \mathrm{M}^{-1} \mathrm{~s}^{-1}$. The solubility of this fluorogenic substrate may be increased by addition of other hydrophilic groups into its structure, e.g. by incorporation of Arg residues at the $\mathrm{C}$ - and $\mathrm{N}$-ends of substrate.

Fluorogenic peptide substrate of HIV-1 protease based on FRET may be used not only in steady-state fluorescence measurements but also in liquid chromatography assays, microscopy and other biological and clinical applications.

\section{A. I. Корнелюк, A. Г. Терентьев, С. Фiшер, T. Портер}

\section{СИНТЕЗ ТА ХАРАКТЕРИСТИХА ФЛЮОРОГЕННОГО \\ ПІЕПТИДНОГО СУБСТРАТУ ВLЛ-1 ПРОТЕАЗИ НА ОСНОВI \\ ФЛЮOPECUEHTHOГO PEЗOHAHCHOГO ПEPEHOCУ EHEPII}

Perrome

Проведено хімінний синтез флооротенного пептидного субстрату ВLЛ-1 протеази. по мае структуру Dns-SQNYPTVWL і відповідае сайту розщеллення $p / 7 / p 24$ у 8 g-лоліпротеікі вірусу імунодефіциту людини.Приншип використання даного субстрату базустьст на резонанстому переносі енергї збудження між донором - здлитком Тю і акцептором - дансильною групою. Встановлеко, що гідроліз флюорогенного пептидного субстрату рекомбінантною ВلЛ-1 протеазою призводить до падіння інтенсивності флюоресценціі дансильноі групи $\mathfrak{i}$ одночасното зростання триттофановоі флюоресценції пнаслідох порушення резонансного переносу енергі3 між донором і ахцеттором. За допомогою високоефективної рідинної хроматотрафіЈ в оберненій фаяі зафіксовано пояпу пептидів, эхі $\varepsilon$ продуктами гідролізу субстрату. Вкзначено хінетичні параметрн гідролізу флюорогенного пелткдного субстрату вLЛ-1 протеазою: $K_{M}-29$ мхM, $k_{\text {cat }}=$ $=5,4 \mathrm{c}^{-1}$ та $k_{\text {rat }} / K_{M}=180000 \mathrm{M}^{-1} \mathrm{c}^{-1}$

\section{REFERENCES}

1. Krausslich H.-G., Wimmer E. Viral proteinases // Annu. Rev. Biochem.-1988.-57.P. $701-754$.

2. Wlodaver A, Miller M., Jaskolski $M$. ef of Concerved folding in retroviral proteases: crystal structure of a synthetic HN-1 protease // Science. - 1989.-245, N 4918.-P. 616-621.

3. Koht N., Emini $E$, Sctleif $W$. et al. Active human immunodeficiency virus protease is required for viral infectivity // Proc. Na1. Acad. Sci. USA. -1988.-85.-P. 4686-4690.

4. Mitsuya H., Yorchoan R, Broder S. Molecalar targets for AIDS therapy // Science.-1990.249.-P. $1533-1544$.

5. Meek T. D. Inhibitors of HTV-1 protease // J. Enzyme Inhibition:-1992,-6.-P. 65-98.

6. Wladawer A., Erictson J. W. Structure-based inhibitors of HIV-1 protease // Annu. Rev. Blochem.-1993.-62.-P. 543-585. 
7. Crais J. C., Duncan I. B., Whittaker L., Roberts N. A. Anttvinl synersy between inhibitors of HIV proteinawe and reverse transcriptase // Anttitral Chea. and Chenother.-1993.-4.P. $161-166$.

8. Tomaszek T, A, Magaard V. W.. Bryen H. G. et al. Chromophoric peptide auberrates for the spectrophotometric assay of HiV-1 proteace // Biochem. and Biophys. Res. Communs.-1990.-168, N 1.-P. 274-280.

9. Matayash E, D., Wang G. T., Kraft G. A., Erickson J. Novel fluorogenic atbatrates for agsaying retroviral proteases by resonance energy transfer // Science. -1990.-2A7.-P. 954958.

10. Wang G. T., Matayoshi E. D., Huffaket H., Kraffi G. A. Design and oynthesis of new fluorogentc HIV protease substrates based on resonance energy transfer // Tetrahedron Lett. $-1990 .-31$, N 45.-P. 6493-6496.

11. Geoghegan $K$. F., Spencer R. W., Danley D. E. et al. Fluoreacence-bened continuous amay for the aspartyl protease of human immunodeficiency virus-1 // FEBS lett.-1990.-262. N 1.-P. 119-122.

12. Wu P., Brand $L$. Resonance energy transfer: methods and applications // Analyt Biochem.1994.-218. -P. $1-13$.

13. Latt S. A., Auld D. S., Vallee B. L. Fuorescence determination of carboxypeptidane A activity based on electronic energy transfer // Ibid.-1972.-50, N 1.-P. 56-62.

14. Meek T. D., Dayton B. D., Metcalf B. W. et al. Human immunodeficiency virus 1 protease expressed in E.coli behaves as a dimeric aspartic protease // Proc. Nat. Acad. Sci. USA. $-1989 .-86, \mathrm{~N}$ 6.-P. $1841-1845$.

15. Gershkovich A. A, Kibirev $\boldsymbol{V}$. $K$. Synthesis of peptides. Reagents and methods. - Kiev: Naukova dumka, $1987 .-264 \mathrm{p}$.

16. Roeske R., Gesellchen P. Reaction of potassium salts of $\mathrm{Boc}$ amino acids with chloromethyi polystyrene catalyzed by 18-crowt-6// Tetrahedron Lett.-1976.-N 38.-P. 3369-3372.

17. Filippova 1. $Y_{L}$, Lysogorskrya $E$. N., Oksenoit $E$. S. et al. Intramolecular quenched fluorescent substrates for aspartic proteinases // Bioorg. Khimiya,-1986.-12, N 9.-P. 1172-1180.

18. Darke P. L, Nutt R. F., Brady $S$. $F$. et al HIV-1 protease specificity of peptide cleavage is sufficient for processing of gag and pol polyproteins // Biochem. and Biophys. Res. Communs, $-1988 .-156$, N 1.-P. 297-303. 